\title{
ERRATUM
}

\section{Laparoscopic Pyloromyotomy: A Modified Simple Technique}

\author{
Mohammed Omer Anwar*1, Yasser Al Omran ${ }^{1}$, Saeed Al-Hindi² \\ 1 Barts and the London School of Medicine and Dentistry, Garrod Building, Turner Street, Whitechapel, \\ London, E1 2AD, United Kingdom \\ 2 Salmaniya Medical Complex, Manama, Kingdom of Bahrain
}

\begin{abstract}
This is an open-access article distributed under the terms of the Creative Commons Attribution License, which permits unrestricted use,
\end{abstract} distribution, and reproduction in any medium, provided the original work is properly cited.

\section{ERRATUM}

It is regretted that the first and last names for the author Yasser Al Omran was published wrong for the manuscript entitled "Laparoscopic Pyloromyotomy: A Modified Simple Technique" published as original article in Journal of Neonatal Surgery volume 5 issue 1. The corrected first name is "Yasser" and last name is "Al Omran". All the authors contributed equally in the manuscript and share equal first authorship where applicable.

Address for Correspondence*:

Mohammed Omer Anwar,

Barts and the London School of Medicine and Dentistry, Garrod Building, Turner Street, Whitechapel,

London, E1 2AD, United Kingdom

E mail: m.o.anwar@smd11.qmul.ac.uk

(C) 2016, Journal of Neonatal Surgery

Conflict of interest: None

Source of Support: Nil

How to cite: Anwar MO, Al Omran Y, Al-Hindi S. Laparoscopic pyloromyotomy: a modified simple technique. J Neonat Surg. 2016 ; 5:26. 